Article

\title{
Resignification Practices of Youth in Zona da Mata, Brazil in the Transition Toward Agroecology
}

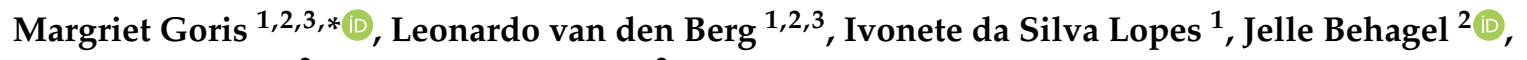 \\ Gerard Verschoor ${ }^{3}$ and Esther Turnhout ${ }^{2}$ \\ 1 Rural Economy Department, Rural Extension group, University of Viçosa, Viçosa 36570-900, Brazil; \\ leonardo.vandenberg@wur.nl (L.v.d.B.); ivonetesilvalopes@gmail.com (I.d.S.L.) \\ 2 Environmental Sciences, Forest and Nature Conservation Policy group, Wageningen University, \\ Wageningen 6700 AA, The Netherlands; jelle.behagel@wur.nl (J.B.); esther.turnhout@wur.nl (E.T.) \\ 3 Centre for Space, Place and Society, Sociology of Development and Change group, Wageningen University, \\ Wageningen 6700 EW, The Netherlands; gerard.verschoor@wur.nl \\ * Correspondence: margriet.goris@wur.nl
}

Received: 14 September 2018; Accepted: 23 December 2018; Published: 2 January 2019

check for updates

\begin{abstract}
Youth play an important role in the transition toward agroecology through practices of resignification. This article discusses how young people resignify agroecology by taking part in education initiatives that originate from social movements, and that aim to strengthen young peoples' abilities to reflect on their practices and realities. We used action research to create films with young agroecologists in the region of Zona da Mata Mineira, Brazil. Our analysis draws on films, interviews and participatory observations made during thirteen workshops to visualize the agroecological practices and visions of youth. We explore how social frames-e.g., the specific ways in which people understand reality—shape practices and how these frames are actively changed by youth. The findings show how frames are changed during (1) frame amplification by building on existing local values; (2) frame bridging by linking with other social movements; (3) frame extension by inclusion of new frames; and (4) frame transformation by altering the meaning of agroecology. We find that young people who engage with agroecology contribute to processes of repeasantization that rework local culture to be more inclusive of different populations, generations and genders, and that they foster an appreciation of the interconnectedness of humans and nature.
\end{abstract}

Keywords: agroecology; repeasantization; transition; youth; gender; social movement; framing strategies; resignification

\section{Introduction}

Increasingly, actors who are working for transformative change toward sustainable food systems do so under the banner of agroecology [1]. What agroecology stands for is disputed among and between scientists and social movements. Rivera-Ferre [2] shows that different narratives on agroecology of national and international actors in the political arena have a "different focus in terms of scale (from farm to the food system) and dimensions of agroecology (ecological and techno-productive, socio-economic, socio-political and cultural) [2] (p. 679)." In addition, several authors [3,4] highlight a risk of co-optation of the term by agribusiness for greenwashing of their activities. This article explores a grassroots' perspective of how young farmers contribute to this debate. It does so by visualizing how youth identify with agroecology and resignify it through various practices. We understand resignification as the ability to articulate meanings in new ways that are often counter hegemony, i.e., that challenge existing interpretations of concepts both in a social and political way. 
In Zona da Mata Mineira, Brazil—which is the geographical focus of this article-agroecology is a result of a process of repeasantization wherein farm workers and rural laborers have (collectively) bought land and replaced external resources with local, ecological resources [5]. Repeasantization is considered a quantitative process of (young) people moving from non-agricultural occupations to peasant farming. Repeasantisation also describes a qualitative shift from a more entrepreneurial toward a more peasant-like way of farming. This entails engaging in practices that (re)ground productive activities in local and natural resources and thereby allow farmers to increase their autonomy vis a vis external knowledge and global markets [6] (p. 28). The cultural and knowledge base of the peasantry is shaped in interaction with living nature. Through this interaction, complex farming systems have been created that are: adapted to local conditions; do not depend on chemical fertilizers, pesticides, or other technologies of modern agricultural science [7]; and, do not rely on import markets for food consumption. Garcia Júnior [8] explains that peasant production can be connected to markets without being (fully) capitalist. The ownership of knowledge about agricultural production and the possibility of consuming and selling their own produce limits the commodification of peasants' labor.

Few studies discuss how and why young people engage in agroecological farming, how they resignify agroecology in education and/or movement practices, and what space they have for change [9-12]. Studies on de- and repeasantization describe the space of rural youth to re-signify agroecology, but leave substantial room for more detailed exploration. Araghi [13], Rosset et al. [14], and Van der Ploeg [6] discuss depeasantization as driven by state-interventions, land-grabbing, green revolution technologies, and ongoing processes of globalization and economic liberalization, but say little about specific constraints that young people face if they wish to become peasants. De Moura [10], Jurna [15], Londres [11] and Brumer [16] highlight the discrimination of peasants, the invisibility of female work, a need for financial autonomy, a lack of dialogue within the family upon issues of succession, income, and affective relationships among youth as other factors of depeasantization, but they say less about how young people handle these constraints. Accordingly, Botelho [17] notes that issues of diversity, like gender and generational conflicts, need more reflection by agroecological farmers and scientists, among others.

Rural youth have played an important role in social movements in the global south. Ghimire [18] offers multiple explanations for this. First, as youth are at bottom of the socio-economic ladder and are often confronted with systemic exploitation, they have to find resources to start farming or to ensure access to work and dignified working conditions. Second, increased access to education, communication, and transport in the countryside has facilitated the participation of rural youth in social movements. Third, many environmental and social problems, such as pollution of water from mining or land-grabbing by agribusiness, have limited access to land for the next generation of farmers [18]. To explain the transformative role of youth in agroecology, some authors point to a period of personal and societal reflection that young people undergo during in their transition from youth to adulthood $[19,20]$. This in-between phase is what Turner [19] calls a liminal phase, when one's social position is not yet evident, and one has the potential to generate new thoughts and customs.

In Brazil, opportunities for young people to engage with agroecological practices and social movements opened with the emergence of Educação do Campo, which include a range of critical place-based education, and the emergence of political platforms for and by youth at levels ranging from the local to the national $[21,22]$. Educação do Campo was demanded by social movements such as the Landless Workers' Movement (MST) and the National Conference of Bishops in Brazil (CNBB) [23]. After the end of the dictatorship in Brazil in 1985, public debates drew on ideals from Freirean pedagogy [24], arguing that education should respect the diversity and needs of different populations. As a result, the department for Continual Learning, Literacy, and Diversity (Secad) was founded within the ministry of Education in 2004. Several policies were established to support Educação do Campo. One of the policies established is Procampo, a policy that promotes particular training for teachers for Educação do Campo. This vocational training for teachers is called LICENA. These policies were based on specific aspects of Freire's pedagogical work, such as the emphasis on local cultures and knowledges, 
and the necessity of engaging learners in a process to perceive reality not as something static but as something which is constantly in transformation, thus also recognizing learning as a political activity [24]. The emerge of political platforms for and by youth in peasant organizations is also a result of social movement work, which emphasized the role of youth, 'youth as protagonists' [10,25].

Processes through which subjects become political by valorizing local culture and exposing marginalization have been studied across the globe. Rossato [22] describes how social movement activities by the Movement of Dam Affected People (MAB) in Brazil enabled young activists to learn to appreciate their local culture and gain an understanding of how social systems work. This process enabled young people to engage in a process of transformation of the social system. Howarth [26] describes how Bantu Stephen Biko of the Black Consciousness Movement in South Africa initiated a similar process. Biko made a call to valorize African ideas and traditions in order to infuse black people with pride and dignity and enhance their understanding of the broader social system. In this process, African ideas are also re-worked: "the movement of Africanization is checked by the specifically 'modern' context in which the ideology of Black Consciousness was compelled to function [26] (p. 70)." In the Zona da Mata Mineira, agroecology has been understood to result from solidarity networks and social learning "among farmers — based on kinship, friendship and religious movements—and with NGOs and other institutional and political actors [27] (p. 84)." The region hosts various critical place-based education initiatives in agroecology and offers political platforms for and by youth.

This article aims to answer the question of how young people contribute to the agroecological movement through resignification practices. In the following section we elaborate on the concepts of resignification and framing strategies by social movements. Next, we describe how action research and ethno-videography were used as a research strategy. In the results section we present framing strategies that resignify agroecology by drawing on nine films made by young agroecologists. We then discuss the role of youth in resignification practices. We conclude that the youth are bringing new energy to and raising new issues within agroecology as a social movement.

\section{Resignification and Framing Strategies of Social Movements}

Resignification can be considered part of a political project. According to Lloyd [28] and Butler [29], "the politics of resignifications is about politics apprehended (in part) as the capacity to recite language oppositionally so that hegemonic terms take on alternative, counter-hegemonic meanings [28]". In other words, processes of resignification can become political if they rearticulate existing knowledge, ideas, and norms from dominant discourses (for example about farming) in new ways. According to Butler [29], resignification of norms is a means to re-work the weakness (emphasis by Butler) in the norm. She refers to the ambiguity of concepts and the possibility to link them to new practices, localities, and/or activities. In doing so, these concepts take on new meanings and create space for new forms of political action.

In order to understanding the role of youth in repeasantization, it is important to understand the process of resignification. Repeasantization involves resignification when new meanings are attached to peasanthood by re-working existing peasant knowledge and values to fit contemporary needs and beliefs. Furthermore, the multiplication of places where youths can articulate their newly-acquired peasant identity also presupposes resignification processes-especially in light of the new peasantry's (precarious) place in society and the youngsters' life phase. Van der Ploeg $[6,30]$ states that, in particular, young successors of conventional farms engage in a qualitative movement of repeasantization by diversifying their farm practices and moving toward more peasant-like agriculture.

Since knowledge and spaces in resignification processes are entwined, Lloyd [28] suggests distinguishing between the 'what', the actual creating of new spaces and activities, and the 'how', the processes that open up discursive spaces and make them possible. To study the 'how', Benford and Snow [31]'s work on social movements is especially helpful. They describe how social movements use framing strategies to expand themselves in terms of both actors and resources. Van Dijk [32] notes that most of the frames derive from social movements' knowledges and ideologies. 
Benford and Snow [31] identified four types of strategies in which meaning is purposefully altered for strategic reasons: (1) frame bridging, (2) frame amplification, (3) frame extension, and (4) frame transformation [31]. Each strategy is explained below.

First, frame bridging refers to linking frames that are similar in ideology but unconnected in practice, with regard to a specific issue. Benford and Snow [31] indicate that frame bridging is one of the most important framing strategies. Rosset et al. [14] and Holt-Giménez [33] noticed how rural social movements, members of $L a$ Via Campesina (LVC) working on alternative agriculture, sustainable agriculture or low-input farming, all incorporated agroecology within their discourse and practice. This is an example of frame bridging. These (LVC) rural social movements were connected ideologically, but they used different concepts to denote similar practices. By re-signifying alternative agriculture, low-input farming, family based diversified farming, ecological farming, and so on, they expanded the meaning of the concept agroecology. This resignification includes a set of practices converging in a new political discourse of agroecology [28]. Dapia [34] explains the political advantage of frame bridging via building equivalent chains (so-termed by Laclau and Mouffe): the longer the chain of equivalences set up between the demands of various groups, the more difficult it is to neutralize struggles [34].

Second, frame amplification refers to the strengthening or expansion of existing values. This strategy is frequently used by social movements to ensure that specific discursive frames resonate with many people [31]. Howarth [26] and Rossato [22] note that social movements use this strategy for transgressive learning by explicitly highlighting and appreciating people's own local culture, they may become empowered to understand and question the dominant system. For example, Botelho [17] described how agroecological farmers have revitalized an emotional relationship with nature. These agroecological farmers not only build on traditional knowledge but also on traditional relationships with nature such as local values about how to live with nature. The requirements for farmers who wanted to join the Conquista da terra, Joint Land Acquisition Movement in Araponga, Zona da Mata Mineira [5,35] also built on local values, such as the commandments to use the force of animals for collective labor or to participate in mutirões, the exchange of working days without money.

Third, frame extension refers to the extension of an idea to include issues that are important to new groups. By 'emptying out' a concept such as agroecology of its concrete content, it can be made applicable to an increased number of practices and purposes [36]. For example, Shanley et al. [37] describe how the Amazonian social movement, the National Council of Extractivist Populations (CNS), previously a male dominated social movement, let go of its concrete masculine associations and established the Secretariat of Women Extractivists to recruit forest-reliant women. In order to ensure a political discourse responsive to women's needs, the secretariat succeeded in changing the composition of movement leaders to include $30 \%$ women. In another example, the International Forum for Agroecology in Nyéléni, Mali [38], declared support for urban and peri-urban agroecological production, in order to include urban farmers in their movement. Frame extensions can, however, backfire when the lack of concrete content of a leading concept leads to contestations over the 'real' meaning and objectives of a social movement such as agroecology.

Finally, frame transformation refers to changing old meanings and generating new ones. This strategy usually includes aspects of the first three framing strategies, but is characterized by the strong resignification of a concept. A good example from political science is when the suffragette movement in the early 20th century claimed voting rights based on the idea of 'universal' suffrage, where 'universal' in first instance was only intended to mean 'all men'. Pimbert [4] notes that agroecology is used within Climate-smart Agriculture (CSA) to refer to a few agroecological practices in combination with industrial farming. This frame transformation of agroecology leaves out the political transformative character of agroecology and resignifies it as a technology. This example shows that it is not only social movements that use framing strategies and that the meanings of agroecology are continuously subject to resignification.

This article uses frame analysis to explore how young farmers resignify agroecology. These practices of resignification differ from place to place based on the 'situated abilities' of the youth [39], 
even within the study area. As resignification strongly depends on the places where it happens and the role that youth has in society, discursive framings were studied as 'in situ' as possible, as explained below.

\section{Action Research and Ethno-Videography}

This research is part of an international transdisciplinary research program called FOREFRONT which aims to explore actor strategies, functional biodiversity, and ecosystem services in agro-forest areas. In FOREFRONT, local universities draw on action research to collaborate with peasant unions in the region to define research demands and activities, and to discuss research outcomes. Action research refers here to the co-creation of knowledge through local activities defined by the demands and creativity of all participants and which contributes to the community and capacity building of all participants. The researcher takes an active role in this process $[40,41]$. In this research this was done by engaging rural youth in film workshops that were organized and taught by the first author.

In Zona da Mata Mineira, Brasil several peasant unions expressed concerns with regard to the permanence of youth in the countryside. The idea of engaging rural youth in film workshops was seen by them as an opportunity to connect youth to agroecological movement activities. The first film workshops were co-organized with the peasant unions. After that, the first author-who is also a professional filmmaker-was approached by youth organizations to give new or follow-up film-workshops. In total, thirteen film workshops took place from 2017 to 2018, producing 85 films. The majority of the participants in the film workshops come from farms that are agroecological or that are in transition toward agroecology. Most had attended various social movements activities and/or are enrolled in critical place-based education that is directed toward agroecology, such as Educação do Campo and/or LICENA. Participants are thus defined as young agroecologists.

Table 1 shows the municipalities where workshops and film screenings were held and the number of female and male participants that attended each workshop. In the first three municipalities, Araponga, Divino, and Espera Feliz, the film workshops were co-organized with peasant unions. The films made by the young people in Divino were screened at a youth event in Espera Feliz, organized by the youth organizations from Divino and Espera Feliz. The researcher was also approached to give film workshops in Viçosa and Goianá. In Goianá, there was no time during the event for a public screening. The organizers invited the young people to participate via their network. They introduced the film workshop to the young people as a means to share information on cultural and political events, farming practices, and so on, and generate social change. Participants were asked for their prior and informed consent to use their films and recordings of the production process for this research.

Table 1. Participants of the film workshops in Zona da Mata, Minas Gerais, Brazil.

\begin{tabular}{cccccc}
\hline Municipality & $\begin{array}{c}\text { Number of Film } \\
\text { Workshops }\end{array}$ & Women & Men & $\begin{array}{c}\text { Total Participants of } \\
\text { Film Workshops }\end{array}$ & $\begin{array}{c}\text { Number of } \\
\text { Screenings }\end{array}$ \\
\hline Araponga & 2 & 14 & 38 & 52 & 1 \\
Divino & 4 & 29 & 9 & 38 & 2 \\
Espera Feliz & 4 & 19 & 13 & 32 & \\
Goianá & 1 & 5 & 3 & 8 & 1 \\
Viçosa & 4 & 66 & 56 & 122 & 4 \\
Total & 13 & 133 & 119 & 252 & \\
\hline
\end{tabular}

This research employed ethno-videography, which is an established methodology of using video in anthropological research. In various research disciplines video is increasingly used as data [42]. Video can disclose different aspects of (inter)action, it allows data to be obtained through repeated observation and it supports transdisciplinary analysis after the original recording. Participatory film in particular allows the capture of unique framing by community members [43]. This enables self-representative knowledge-sharing which contributes to an equal playing field of diverse knowledge holders [44]. 
Moreover, analyzing moving images and frames ensures rich data in terms of signs, words, and images and it also gives an in-depth look at practices of resignification.

In the film workshops that were part of this action research, the participants shared their experiences of film-making and acquired new knowledge of story-telling, film genres, film techniques, editing, and film dissemination. During the workshops, the young people formed pairs or small groups to visually draw a script, shoot, and edit films using their mobile phones. All decisions about the script, music, film title, and so on, were made by the filmmakers. Depending on the wishes of the youth organization or school, the young people were either given a specific issue to film (either audio-visual memories, aspirations to be (or not) an agroecological farmer and discourse about agriculture) or were left free to choose a topic themselves. Where possible and allowed, the researcher recorded the audio of conversations during the filmmaking and the public screenings of their films.

The transcripts of these audio recordings, the moving images, notes of participatory observation, and ten in-depth interviews provide a more complete picture of why the participants made these films. The films allow for multiple interpretations, but transcripts of the audio recordings during the making-of and interviews with the filmmakers also disclose the intentions of the filmmakers. The filmed material triggered the young agroecologists to discuss self-representations among themselves. The 85 films made by the young agroecologists were first analyzed in terms of main themes, diversity of topics, and active participants/filmmakers. Second, nine films were selected for an in-depth analysis to further identify the role of different framing strategies and to identify practices of resignification. We focused on representations of practices and people in the films and cross-verified our findings with data on the film production process and with the interpretations of the filmmakers. This was done to reflect a broad spectrum of resignification practices found with the youth in the study region.

\section{Results}

\subsection{Film Descriptions (Selection of Nine Films)}

\subsubsection{Film ‘Produção de Farina/Making of Flour'}

The film 'Produção de farinha/Making of flour' (Video S1) was made by a male student of Licenciatura em Educação do Campo (LICENA) in Viçosa, Minas Gerais, a vocational training for teachers for place-based education, initiated by social movements, such as the Landless Workers' Movement (MST) and unions, such as the Federation of Workers in Family Farming (FETRAF). Teachers at this vocational training aim to promote agroecology. The film was made during 'tempo de alternância', the school period that students spent in their own community. The student who made this film is descendent of the indigenous group Tapuio who live in the municipality Coração de Jesus.

The film shows the entire cassava flour production process (Figures 1 and 2). Cassava is a native plant from Brazil, and is a typical indigenous food that became a traditional Brazilian food. The scenes show the production of cassava flour as a collective process and visualize all actors involved: women, men, and elderly and young people. The filmmaker explains in an interview that they make the flour with the support of their family. They do this in a process called mutirão, the exchange of working days without money. The flour is used for their own consumption and to sell in nearby villages. His father sells the flour. He and his brothers and sisters and mother have to ask for money if they want to buy something. This is fine for him: "when it comes to the need to buy something for someone, you take and buy." 


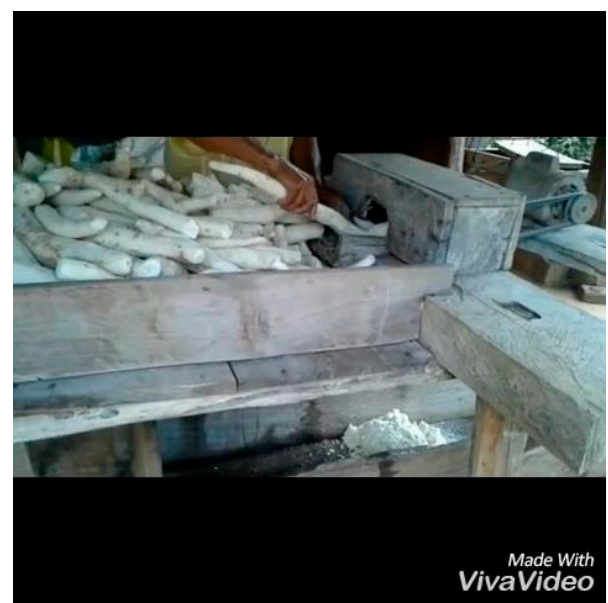

Figure 1. Frame from 'Produção de Farinho/Making of Flour'.

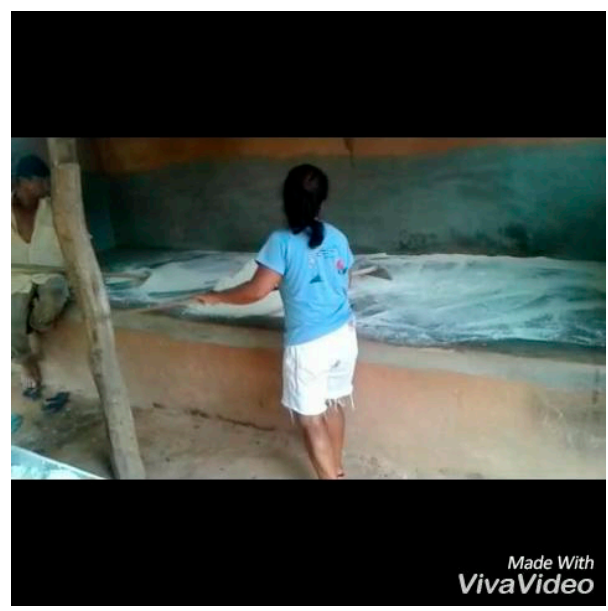

Figure 2. Frame from 'Produção de Farinho/Making of Flour'.

\subsubsection{Film 'Carneiro Hidráulico/Water Pump'}

Another male student from LICENA, a son of farmers in Rio Piracicaba, made an instructional film (Video S2) about a self-made water pump. The film demonstrates how the pump moves the water from one area to another area (Figures 3 and 4). The student explains in the film how the pump functions and why he designed and made the pump: "I am using it here to oxygenate the water for the fish and to keep more water in the area. This makes that we have different carp, lambari. It is essential to keep this carneiro, ram working because the spring here has dried up, so the only oxygen which is here for these fishes is through the water pumped down there."

Figure 4 shows a fish swimming to the surface for oxygen. Figure 3 demonstrates a pump made of recycled materials and other local resources available. The student, who works part-time as mechanic, states in an interview that he made the pump himself because they did not want to rely on expensive electric pumps. His statement is in line with peasant values of autonomy and relying on local sources. He made the pump five years ago to restore the water level without any ambition to use this water for irrigation. Only after an excursion of LICENA to an agroforestry system did he see options to transform his parents' eucalyptus farm to an agroforestry system. After their retirement, he intends to use the water to irrigate the seedlings for the agroforestry system. 


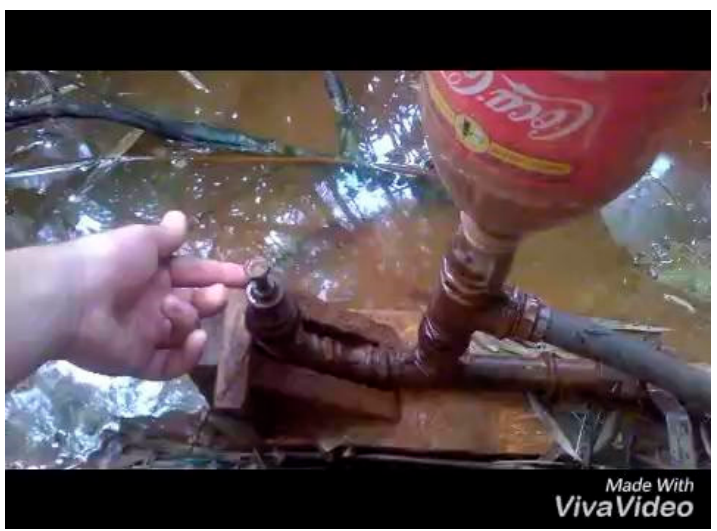

Figure 3. Frame from 'Carneiro Hidráulico/Water Pump'.

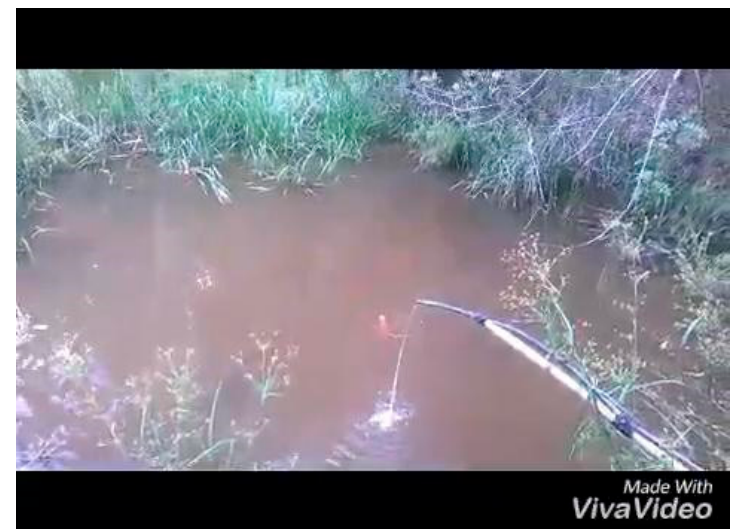

Figure 4. Frame from 'Carneiro Hidráulico/Water Pump'.

\subsubsection{Film 'Plantas Medicinais/Medicinal Plants'}

The film 'Plantas Medicinais/Medicinal Plants' consists of two videos (Video S3). Both videos were made by a female student from LICENA and her grandmother. Together they wrote a script (Figure 5) which indicates the content of the two videos. The first video is about the past use of medicinal plants: "People sought healing, through popular knowledge and existing plants in their midst, benefiting from the natural resources of their region".

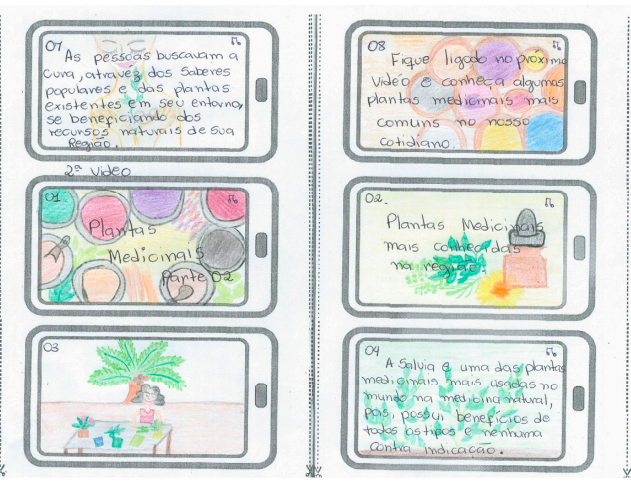

Figure 5. Script from 'Plantas Medicinais/Medicinal Plants'.

In the first video the woman states: "At that time, people had very little resources in the community. People got sick, people had plants, right?" The second video shows that despite the emergence of local health centers, people continue to use medicinal plants in the region. The film shows how knowledge is passed over to the next generation, orally and via books (Figure 6). The grandmother, 
benzedeira, a specialist in alternative medicines, learned it from her family and by following a course at the university.

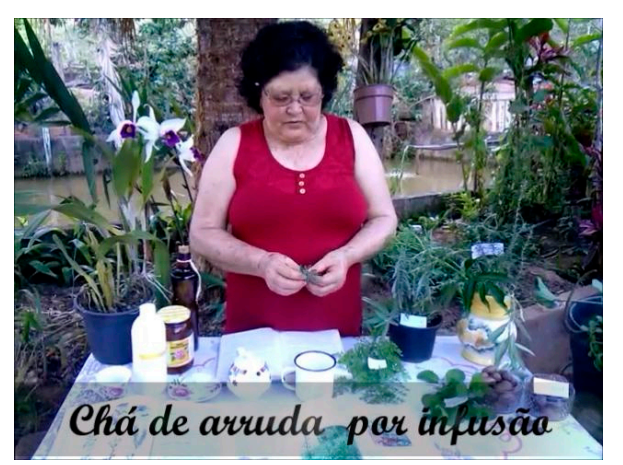

Figure 6. Frame from 'Plantas Medicinais/Medicinal Plants'.

\subsubsection{Film 'Flores Para Viver/Flowers to Live"}

In the first film workshop in Espera Feliz, which took place on an agroecological farm, one of the girls proposed to make a film about flowers. All participants agreed and they made the film 'Flores para viver/Flowers to Live' about the different connections they have with flowers: esthetic purposes, promotion of well-being, and for use as food and medicine. In follow-up meetings young people also stressed the importance of flowers to attract bees for the pollination of their crops.

The film starts with a girl singing about flowers. Then, one by one, the filmmakers present a flower and show their affinity with and knowledge about the presented flower. Remarkably, the person is always presented on an equal level with the plant. If the plant grows low on the ground the person kneels, if the plant becomes very large the person stands next to the flower (Figures 7 and 8). Figure 7 depicts a girl caressing the plant with her hand, showing her affection for the plants.

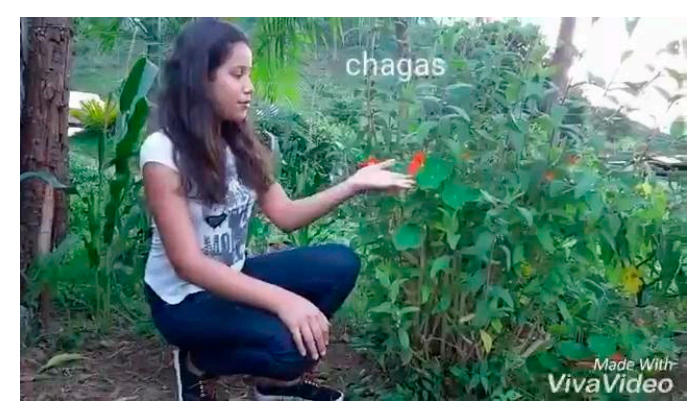

Figure 7. Frame from 'Flores para viver/Flowers to Live'.

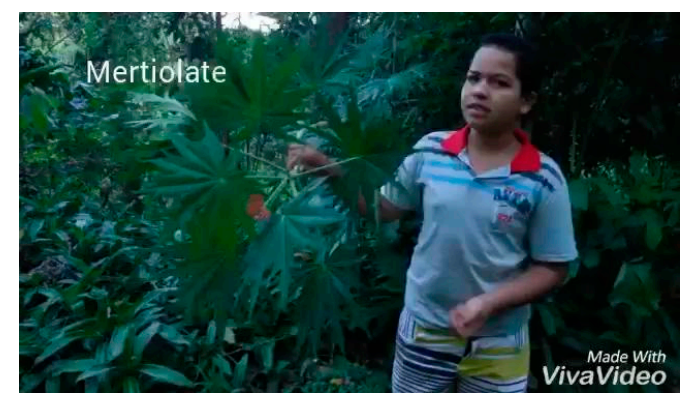

Figure 8. Frame from 'Flores para viver/Flowers to Live'.

4.1.5. Film 'Sem Agricultura Não Existe Juventude/Without Agriculture There Is No Youth'

The reportage 'Sem Agricultura Não Existe Juventude/Without Agriculture There Is No Youth' is filmed by female and male youth from urban and rural areas in and around Divino. The film was recorded at 
a youth weekend organized by Pastoral Juventude Rural (PJR) and ECOJOVEM, a youth organization in Divino. Both organizations are linked to the agroecological movement and organize activities for young people from both rural and urban areas in Divino. They consider agroecology to be for both groups of youth without division. The main theme of the weekend was gender, but the program consisted of a variety of workshops. One of the filmmakers stated that this was appealing to him: "being an agroecological farmer, you are not alone working on your farm, you have these meetings."

The images in the film show the mixture of workshops with traditional practices and innovative practices. For example, local dances were combined with a training on climbing with ropes (Figures 9 and 10), both for sport in nature and to gain experience in safe climbing. Confidence in climbing is important because pruning high trees is a returning farm practice within agroforestry (an agroecological technique) and farmers have mentioned their fear of climbing high trees in informal talks.

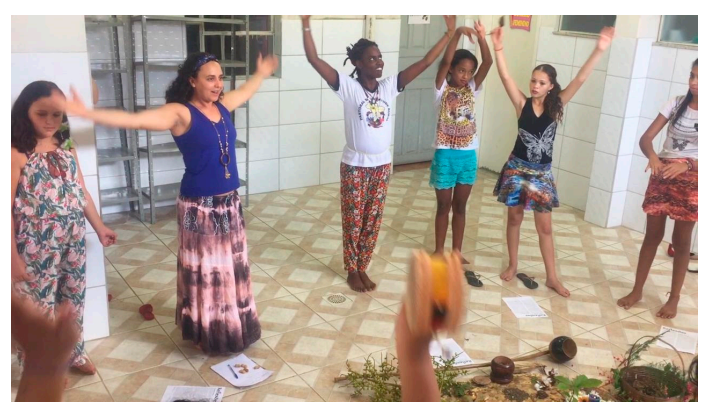

Figure 9. Frame from 'Sem Agricultura Não Existe Juventude/Without Agriculture There Is No Youth'.

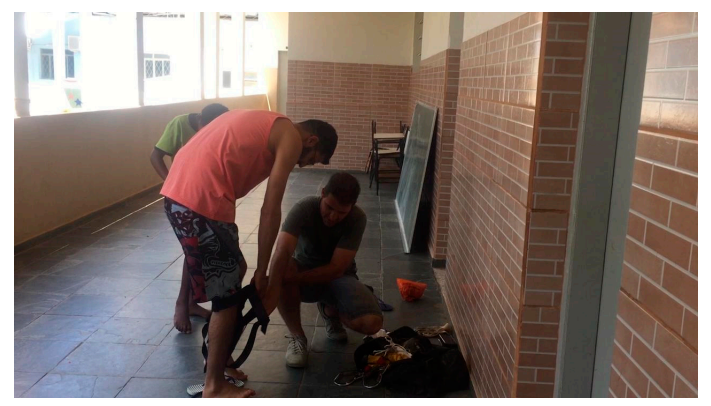

Figure 10. Frame from 'Sem Agricultura Não Existe Juventude/Without Agriculture There Is No Youth'.

\subsubsection{Film at Quilombola Macaúbas Palmito Without Title}

The film (Video S4) at the Quilombo Macaúbas Palmito, a traditional community of descendants of black enslaved people, was made by a female LICENA student during the school period she spends in her community. Like other films, frames (Figures 11 and 12) and spoken words visualize and valorize the variety of products made by farmers: "Here is our exhibition of handicrafts, carpets, blouses." With the support of a municipal public youth program, Bocaiúva young people and women learned to make this handicraft to achieve some financial autonomy.

The main theme of the film is the commemoration of the Black Consciousness Day. Various popular artworks filmed emphasize the message of this day, such as the poster (Figure 13) with the text: "Inside we are all the same color." The young child in Figure 14, is introduced with the words: "We have here our princess". It is an appreciation (of the beauty) of African women, used to emphasize that black is beautiful (in contrast to the perceived dominant narrative that only white can be beautiful). The filmmaker states that with the formal recognition of the Quilombo Macaúbas Palmito in 2016, community members started to engage in the national movement of black rural Quilombolas. Since then, they commemorate this day and started to valorize their African traditions. The filmmaker gives as an example in the interview about the film: "They began to cultivate African culture, their hair 
looser, to accept that they have curly hair, those things that once were all smoothed and pulled, not now, they are accepting more."

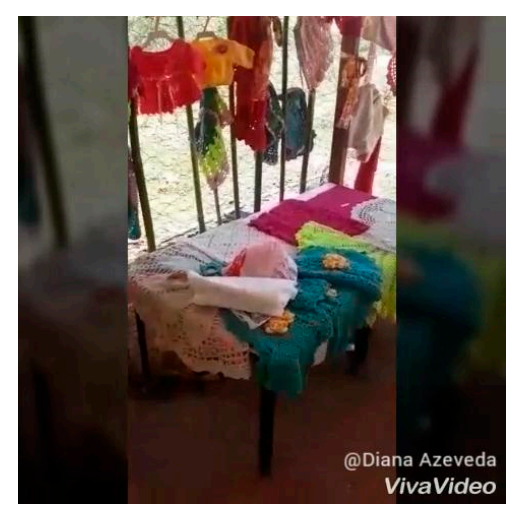

Figure 11. Frame from film at Quilombola Macaúbas Palmito without title.

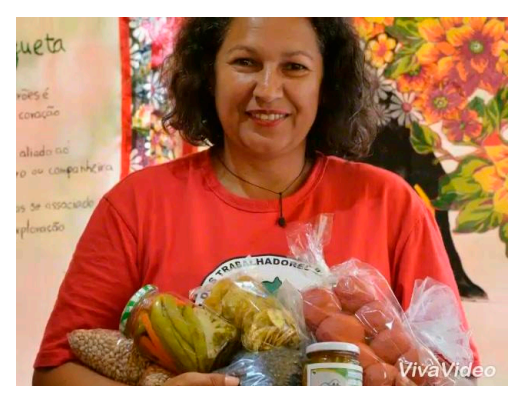

Figure 12. Frame from 'Ipês de Várias Cores/Ipês in Various Colors'.

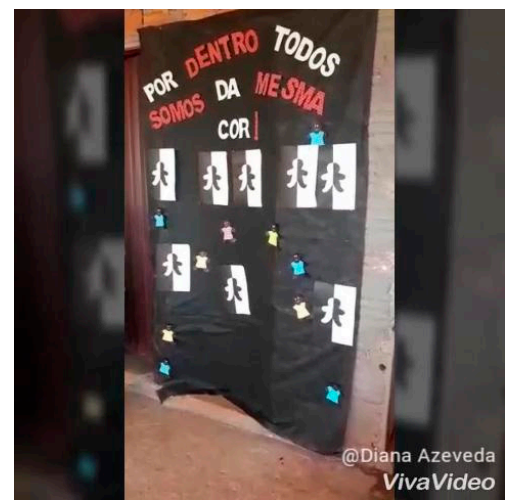

Figure 13. Frame from film at Quilombola Macaúbas Palmito without title.

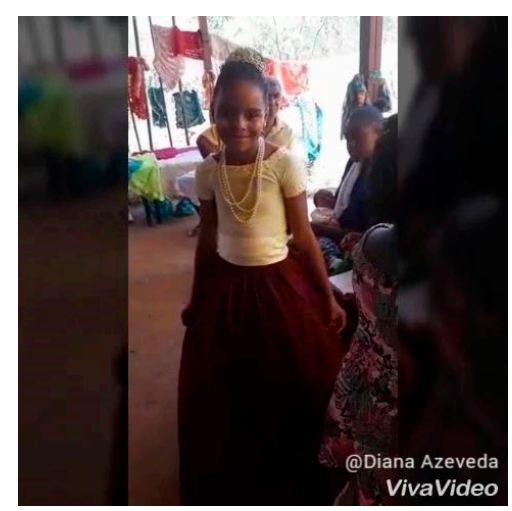

Figure 14. Frame from film at Quilombola Macaúbas Palmito without title. 


\subsubsection{Film 'Ipês de Várias Cores/Ipês in Various Colors'}

The film 'Ipês de vários cores/Ipês in Various Colors' was made by a young woman of the Landless Workers' Movement (MST) at the MST settlement 'Denis Gonçalves' in Goianá. In the film, the issues of gender and racialized bodies are connected. The film title is symbolic for what the filmmaker wants to bring across with her film.

Contrary to the title, the film portrays no images of the native Ipê trees with blossoms in different colors. The film does portray a diverse group of women (Figure 15) who all had to 'conquer' land for farming. There are images of broken chains and locks (Figure 16) symbolizing Afro-Brazilian women with a history of enslaved families and images of female peasants who used to be rural workers or sharecroppers. One of the women in the film shares her aspiration: "Today we try to unite the women without land."

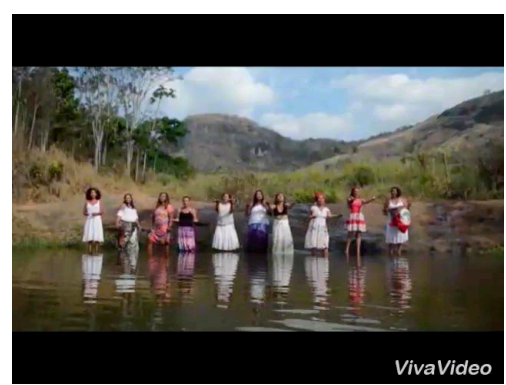

Figure 15. Frame from 'Ipês de Várias Cores/Ipês in Various Colors'.

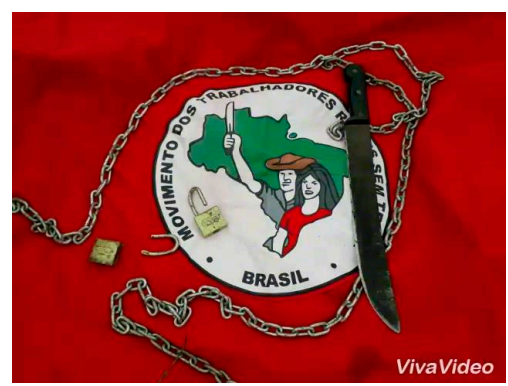

Figure 16. Frame from 'Ipês de Várias Cores/Ipês in Various Colors'.

\subsubsection{Film 'Preconceitos em Dois Atos/Prejudices in Two Acts'}

The film 'Preconceitos em Dois Atos/Prejudices in Two Acts' is made by sons and daughters of farmers that are member of the peasant union in Espera Feliz. Audio recordings of the script-making of this film, made by a mixed group of young female and male peasants, reveal that they wanted to make a docu-soap and, in line with this format, the film had to have a happy end.

Filmmaker 1: "I have an idea (... ) In this case, I can sell-Let's assume that I am selling the corn to another person and with this money I can go to the faculty." Filmmaker 2: "Incredible, you are already thinking about the future."

Notably, the young woman thinks that she needs to pay for follow-up education. She is thinking of enrolling in a private university rather than a public university. Public universities are free in Brazil but it is more difficult get accepted. The possibility of obtaining a grant to pay your daily expenses and enrolling in a public university seems to be out of her scope. Although public policies in Brazil establish a quota and try to democratize access to public universities, many people continue to think that public universities are not for them.

The movie starts with two young persons who laugh at a young female peasant at work. The young female peasant is crying and another person passing by is comforting her: "Don't cry, one day you will succeed to study." Later on in the film we see the young female peasant selling her products 
(Figure 17) and entering the university. Contrary to the daily reality of many young women in this region as described by the literature on the problems young female peasants face $[10,15,16]$, the woman in the film achieved financial autonomy. In the second part of the film, made by a different group of female and male young peasants, a young female peasant goes to school and at the same time works at the farm. In between the two parts of the film the editors (both groups of young peasants) included the text: "Even with prejudices, many women are proud of what they do". The second act shows the double workload of the young women; making it visible and appreciating their work. This part ends with a scene in which the main character (Figure 18) is playing football with her brothers, again breaking with presumed gender roles that football is for men. In the second part of the film the narrator of the film is a young black woman (Figure 19), just like in other films made by the youth. This is noteworthy, as most presenters in the mainstream media in Brazil have a light skin tone.

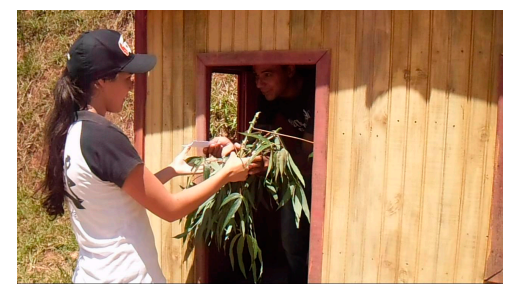

Figure 17. Frame from 'Preconceitos em Dois Atos/Prejudices in Two Acts'.

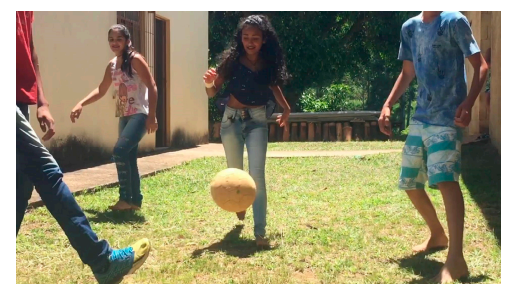

Figure 18. Frame from 'Preconceitos em Dois Atos/Prejudices in Two Acts'.

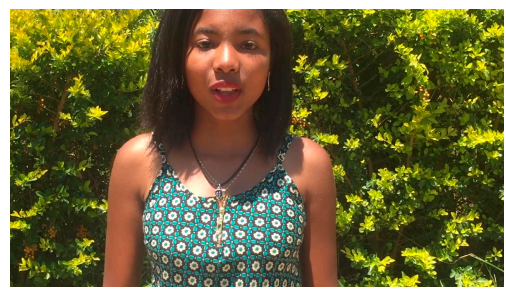

Figure 19. Frame from 'Preconceitos em Dois Atos/Prejudices in Two Acts'.

\subsubsection{Film 'Dois Amigos/Two Friends'}

The docu-soap "Dois amigos, Two friends" is made by young students of the Escola Familia Agrícola,-EFA Puris, a critical place-based high school in Araponga, directed toward agroecology and initiated by Puri (indigenous) farmers. The film tells the story of two friends and the use of pesticides (Figures 20 and 21). One of them is a conventional farmer and the other one is an agroecological farmer. Their different viewpoints become evident in the following conversation in the film:

Conventional farmer: "If you use this remedy in your cultures, I assure you that you will be surprised, everything stays green."

Agroecological farmer: "But it is not a remedy, is it?"

Conventional farmer: "It is."

Agroecological farmer: "It is a poison."

At the end of the film the conventional farmer becomes sick due to the use of pesticides and dies. The film reveals how the lives of agroecological farmers are intertwined with the lives of conventional 
farmers, representing the reality of the young filmmakers at the school EFA-Puris, who come from both agroecological and conventional farms. The two friends in the film do not have the same ideology but are friends, building on local values of solidarity.

Conventional farmer: "If you need help, just look for me".

Agroecological farmer: "If you need help also..."

Later in the film the agroecological farmer is there when the conventional farmer becomes sick and dies. The film is reaching out to conventional farmers, trying to build ties with those conventional farmers who care about their own health.

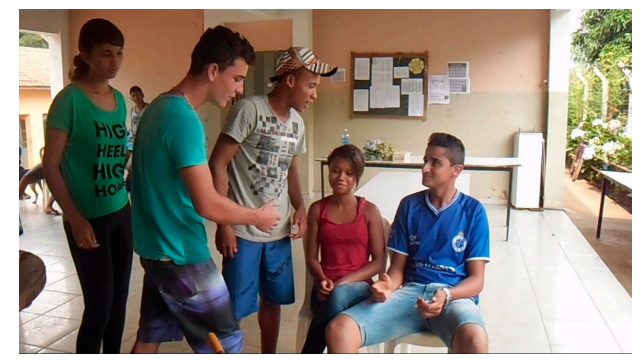

Figure 20. Frame from 'Dois Amigos/Two Friends'.

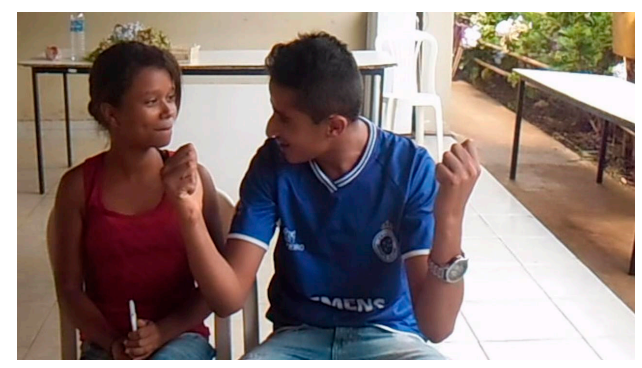

Figure 21. Frame from 'Dois Amigos/Two Friends'.

\subsection{Resignifying Agroecology}

The nine films discussed above all include examples of framing strategies. Three films (Table 2) specifically illustrate frame bridging (i.e., linking different societal groups with a similar ideology). These three films mirror Brazilian society which is culturally heterogeneous and moreover has immense social inequality. (Rural) social movements emerged to fight for land reform and social equality and the young agroecologist filmmakers stress the urgency of these issues. To recognize and enhance the diversity of people as well as to grow the agroecological movement, bridges are created with social movements that share the same ideology.

In the film 'Without agriculture there is no youth' one of the interviewed female peasants stresses that agroecology is more than co-production of human activities with natural processes: "Agroecology for me is a way of treating people, animals, especially on the land that we take care of with love. Knowing how to treat the land, knowing that it has life, that it is not only something that we use and throw away, it is about knowing how to care, take this meeting today, this also shows the diversity of people, how these people interact, for me this is agroecology." The young woman makes an analogy between the diversity of the ecosystem and care for land and recognizing the diversity of people and care for people. She is thus resignifying 'care for land' to 'care for land and people'. A follow-up interview with a young peasant who participates in the youth group of Articulação Nacional de Agroecologia, (ANA) builds on this idea: "This group is very important because our agroecology today needs more young people, more women and I would say, she needs also more colors. She needs to have people of all ethnicities, she needs all people together, because at the end of the story, agroecology is about diversity." In their eyes agroecology is not only about working with biodiversity but also about appreciating cultural diversity. 
Table 2. Frame bridging.

\begin{tabular}{ccc}
\hline Movies & Social Movements & Frames \\
\hline $\begin{array}{c}\text { Without agriculture there is no youth } \\
\text { Film at Quilombola Macaúbas } \\
\text { Palmito without title }\end{array}$ & $\begin{array}{c}\text { Various social movements } \\
\text { Movement of black rural } \\
\text { Quilombolas }\end{array}$ & "Inside diversity of people, how these are all the same color" \\
\hline Ipês in various colors & $\begin{array}{c}\text { Landless Workers' } \\
\text { Movement }\end{array}$ & "Today we try to unite the women \\
without land."
\end{tabular}

The most frequent framing strategy identified in the movies is frame amplification (Table 3), in which local values and beliefs are emphasized. Frame amplification ensures that frames resonate with potentially interested people [31]. Additionally, it is important that processes of transgressive learning start in social movement practices that valorize local culture $[22,26]$.

Table 3. Frame amplification.

\begin{tabular}{cc}
\hline Movies & Frames \\
\hline Making of Flour & Collective work to produce flour, mutirões \\
\hline Film at Quilombola Macaúbas Palmito without title & Natural afro hair style without chemical treatment \\
\hline Medicinal Plants & $\begin{array}{c}\text { Traditional knowledge on healing people with } \\
\text { medicinal plants }\end{array}$ \\
\hline Flowers to live & Affective relationships with nature \\
\hline Without Agriculture There is No Youth & Traditional farming practices without pesticides \\
\hline Two Friends & Solidarity \\
\hline
\end{tabular}

By re-establishing ancient relationships with nature, suppressed by modernity and the green revolution [17], the meaning of agroecology in the film 'Flowers to live' is resignified from 'co-production with nature' to 'co-production and interconnectedness of humans and nature'. The spoken words in the film and follow-up interviews reveal how people talk about agroecological farming and movement practices in terms of personal relationships. In the film 'Flowers to Live' one of the male characters states: "Because she is a flower ... her color is not common in this region and because she is a flower of a very tasteful fruit, you can even make a farofa (typical Brazilian dish of baked cassava flour mixed with other ingredients), there are diverse forms you can feed yourself with her." The film shows how affinity with local nature and culture are interwoven.

The way local practices are filmed, showing complete production processes, close-ups of tools, all people involved, no visual effects, the pure esthetics of these practices (see Figures 1 and 2 from the film 'Making of Flour') reveal how these practices are appreciated by the young filmmakers. The way they filmed it, shows that they are aware of their role of (re)producers of local knowledge on production, and of culture. The filmmaker of 'Making of flour' notes that he wants to continue with making flour, candies and rapadura (candy made from sugar cane). With the new knowledge acquired at LICENA he resignified various farming practices at home. For example, he changed from the single cropping of beans to intercropping beans with corn and pumpkin and from using pesticides to using homemade liquids for natural pest management.

Frame extension (Table 4) is often a result of alignments between social movements which share a similar ideology but emphasizing different issues. The film 'Prejudice in Two Acts' adds an image of a young female peasant receiving money for her work. The signification of 'peasant autonomy' [8] is extended to mean 'peasant autonomy for male and female peasants' on their workforce. This type of alignment with the feminist movement present in the local family farmers union is essential for young 
female peasants. Literature on depeasantization in Zona da Mata [10] shows that if gender issues are not tackled, depeasantization may take place, especially among young female peasants.

Table 4. Frame extension.

\begin{tabular}{ll}
\hline \multicolumn{1}{c}{ Movies } & \multicolumn{1}{c}{ Frames } \\
\hline $\begin{array}{l}\text { Film at Quilombola Macaúbas } \\
\text { Palmito without title }\end{array}$ & $\begin{array}{l}\text { Image of a young black actress playing a princess emphasizing that } \\
\text { black is beautiful and symbolizing the struggle against racism }\end{array}$ \\
\hline Ipês in Various Colors & $\begin{array}{l}\text { Image of MST flag with broken chains and locks symbolizing the } \\
\text { struggle against racism and the fight for land reform }\end{array}$ \\
\hline Prejudice in Two Acts & Young female peasant receives money for her work \\
\hline
\end{tabular}

Frame extension of agroecology to include feminism was seen to be enhanced by social movement building. In the municipalities where women are organized and embrace feminist ideology, the gender issue is more prominent in the films made by young people. One of the mothers of a young filmmaker, who received an award from former Brazilian president Dilma Rousseff for her agroecological work with women in Zona da Mata, explains how the last decade they have been organizing women in Zona da Mata Mineira together with the Centre for Alternative Farming, CTA. She notes that the women came together to talk about violence against women, including structural violence: "Look, the women also have the right to speak, to participate when the money comes in from the production, because many times the women don't participate, they harvest the coffee, they just work, but they don't have their own money, they work in order for other people to have money, this is violence." The young people visualize this perspective and bring it into the spotlight. This is less the case in municipalities where women are not organized, as the film 'Dois Amigos/Two Friends' shows. In this film, women have a passive role and men literally fill up the place (Figures 20 and 21).

Frame transformation (Table 5) happens when old meanings are significantly re-signified. In the film 'Two Friends' the word 'remedy' for pesticides (the word used by the conventional farmer) is transformed to the word 'poison' for pesticides (the word used by the agroecological farmer). This type of resignification of farming practices is meaningful. The filmmakers, students from conventional and agroecological farms, note that the transition toward agroecology started at their farms with using less pesticides, often because of health issues. The students are the first generation within their families who study at Educação do Campo, and parents of the students ask, as one of the filmmakers notes: "you are studying at the EFA, so you can explain to me about the ideal practices for planting". Others are more reluctant as one of the female students of EFA notes: "He would put it like this: what is this, girl? You don't know nothing, let me use my product here that I know. No, Dad, but you will kill the plant. Oh, no, this is good for the plant. But where he used, crops decreased a lot."

Table 5. Frame transformation.

\begin{tabular}{cc}
\hline Movies & \multicolumn{1}{c}{ Frames } \\
\hline Flowers to live & "there are diverse forms you can feed yourself with her" \\
\hline & Conventional farmer: "If you use this remedy in your cultures, I assure \\
& you that you will be surprised, everything stays green." \\
Two friends & Agroecological farmer: "But it is not a remedy, is it?" \\
& Conventional farmer: "It is." \\
& Agroecological farmer: "It is poison." \\
\hline
\end{tabular}

Other students from conventional farms also stated in their interviews that one of the first things they succeeded at, was to convince their parents to use less or no pesticides. Afterwards they introduced various other agroecological practices into their homes, such as crop diversification, natural pest management and so on. This critical place based education, 'Educação do Campo' and the teachers 
vocational training for this type of education, LICENA explains partly the observation of Cacho et al. [9] that young people have a more agroecological vision than the previous generation in the region.

Notably, young farmers also used the word resignify (resignificar) in the interviews. As another student from LICENA stated in an interview: "what made the difference, to be at peasant to peasant meetings, to go to another community and to see that it works there, let's bring it to our place, but let's resignify, some things, a syrup for natural pest management, sometimes the ingredients, the resources we had were not the same as at the place of the meeting, lately we don't talk about resources but about the kindness of nature." To talk about the kindness of nature instead of nature as resources is also an example of frame transformation, the meaning significantly changed to express the interconnectedness of humans and nature.

\subsection{Reflecting on Resignification}

Equivalent chains, as described by Laclau and Mouffe [45], can be identified in many of the 85 films. There are equivalent chains made with conventional farmers who care about their health and with traditional farmers who already work with a set of agroecological practices. As one of the interviewed woman in the film 'Without Agriculture There Is No Youth' stated: "Persons, without knowing what agroecology is, know how to manage the land without agro-toxics as this has been passed on from generation to generation." A specific contribution of the youth is that they put a spotlight on young, female, black and LGBT farmers who are also making the transition to agroecology. By bridging the agroecological movement with the feminist and black movement, social differences among farmers are equated: they are all agroecological farmers.

Many films made by the young people show that agroecology is not only about producing healthy food, but also about producing other natural based products such as medicinal plants. The filmmaker of 'medicinal plants' and the women from the local women's group she initiated are starting to produce clothes, popular art and biodegradable cleaning, and body products. The agroecological peasants are producing non-food end products which usually tend to be processed in urban areas. For these young peasants, agroecology is not only about producing food, but also about producing all kinds of nature based products which have been made in co-production with nature and with people in the community.

Several of the young peasants explained in the interviews why mostly young and female peasants are involved in processing and selling food and non-food raw materials. These groups often do not have their own land to make a living, so they explore options in the processing of natural materials: "Young people sold some handicraft, cleaning products, soap, some fruit and vegetables. The young people because they aren't yet the owners of the land, they don't have a guaranteed production." In addition to the financial autonomy these women and youth thus achieve, they have the affinity, knowledge, and skills to produce these things which used to pertain to peasantry. The filmmaker of 'medicinal plants' explains that the idea to start a production collective of women emerged during an excursion of LICENA to another women's organization in the region.

Multiple framing strategies were often depicted in a single film and thus clearly form a topic of relevance for the young filmmakers. For example, the film 'Medicinal Plants' is an example of the simultaneous use of frame amplification, frame extension and frame transformation. Frame amplification, because the women make products which used to pertain to peasantry. Frame extension, as agroecological products are more than food and, as such, the meaning of agroecology transforms from the ecology of the food system to the ecology of the system of natural products.

Images of production were emphasized in many of the films. This can be explained as a strategy for dealing with existing prejudices locally and in the mass media against women, peasants, African descendants, and MST. As a young filmmaker in Espera Feliz states: "I don't care much but when it's too much I say, "Everything comes from the fields, the rice you eat comes from the countryside, the beans that you eat, nothing comes from the industry. It might come from food industry but it is first produced at the farm." And: "When you have to present, they ask what's your name, where do you come from? My name is.., I'm from Vargem Grande (neighborhood at the countryside), so everyone starts like this "he is from the countryside", 
and everyone keeps repeating this." One of the interviewed males in the film 'Without agriculture there is no youth" refers to prejudices against farmers in the film: "My message to youth is to not be ashamed for being at the countryside, too make dirty your hands in the earth, to sweat the entire day, to do hard work because the entire society depends on us, without us nobody eats, wears clothes, there's no other way." The variety of natural products shown in the films is not only frame extension: Agroecology entails more than producing sustainable food: it is also a strategy to transform the negative connotation of peasantry into a positive connotation.

The filmmaking process created many moments of reflection for the young farmers themselves, some of which were fed into and transformed peasant and social movement organizations. One of girls noted during the editing of another film about prejudices: "We do not like to talk about it. It's difficult to say, for example, in a school environment, when you have a lecture about pride, about racism, this person is practically speaking alone, it's very difficult for somebody to express themselves about these issues, even for fear of repression by their colleagues." In the course of the production of the film 'Prejudices in Two Acts' discussions on gender, racialized bodies and lesbian, gay, bisexual and transgender (LGBT) (farmers) popped up without intervention from the researcher. A young peasant who participates in the youth group of ANA and is descendant of the indigenous group Puri explains that it are the young people who put issues such as cultural diversity on the agenda of ANA: "Look, what we already put on the agenda is the participation.. a higher participation of black people, indigenous people, the traditional populations, this was the claim we put there. Also the participation of LGBTs (Lesbian, Gay, Bisexual and Transgenders), this was also stressed. These are demands that come from the youth, but also from other groups." At the regional preparation meetings in Zona da Mata for the national meeting on agroecology, the IV ENA in May 2018, it were also the young people who were publicly stating that feminism, the struggle against racism and homophobia are an essential part of agroecology. Through these actions the youth reaffirmed themselves as protagonists $[10,25]$ in social movement organizations and broadened the social and environmental justice spectrum in which these organizations work.

Educação do Campo and LICENA, critical place-based education based on the work of Freire [24] played a significant role in the recognition of local sustainable farming practices as agroecology. This type of education acknowledges and valorizes local knowledge on agroecological farming and the diversity among agroecological farmers. Students of this education are engaged to re-work local knowledge and experiment in their community via a 'personal professional project'. The filmmaker of the 'Film at Quilombola Macaúbas Palmito without title' explains that she learned at LICENA that their farming practices are agroecological practices: "The community didn't know the term agroecology but those who have access to school and outsiders recognized the agroecological practices." In the same interview another student from the same Quilombola states that she wants to start an agroforestry system after the excursion of LICENA to an agroforestry system: "In relation to the community I have the desire to become an ecologist, I have to be able to buy a bigger piece of land and to make a PP area, which is an area of Permanent Preservation within my property".

Finally, the music of the movies was carefully selected by the filmmakers. The film 'Flowers to Live' starts and ends with a song about flowers. In the song references are made to spiritual experiences: "I am a little flower of Jesus, I am a little flower of Jesus, open your mouth to sing ... " The flowers are a metaphor to express people's place on earth. Comparisons with nature are used for expression of local culture, in which spiritual references are also used to articulate their relation with nature. The music of the film 'Making of Flour', called 'Pausada de Boiadeiro' of Tião Carreiro e Pardinho underlines the importance of memories "I remember this of my childhood", and of culture "the guitar becomes the compass of my heart". At the union's school for rural youth in Espera Feliz a young female filmmaker noted that instruments such as guitar and accordion are characteristic for their culture. The music is in line with the content and images of the film, such as the images of the mutirão which show the use of frame amplification, the building on local culture. The song in the film 'Medicinal Plants', (Brandão) affirms the interconnectedness of humans and nature: "It is mother nature who ensures that we are going to be cured." 


\section{Discussion}

The ongoing request for film workshops indicates that social movements, organizations linked to the agroecological movement, and education in agroecology in Zona da Mata Mineira, Brazil are interested in exploring new affordable techniques, such as films made on smartphones, to share their knowledge, ideas, and values. Calvet-Mir et al. [46] indicate that digital means can indeed be very promising for sharing what they call Traditional Agroecological Knowledge (TAeK). The nine films analyzed in this paper and the broader reflection on all films and the workshops reveal that young agroecologists recognize the value of traditional knowledge, culture and social struggles, and at the same time play an important role in resignifying farming practices. They show, as Gohn [47] also points out, that the development of new knowledge involves new forms of communication and networks of articulation.

An additional value of the film-making is that some of the "docu-soaps" reveal taboos and the struggle to overcome values that marginalize others. The majority of young people involved in this research recognize patriarchal and racist values in their communities and try to replace these values. In a few cases young people admitted to having previously displayed some of this behavior and showed feelings of shame. The soap-genre allows them to discuss issues they do not want to speak about in their own name. During the making of the films and interviews, the young people also talked about sensitive issues such as homosexuality. The fact that these young people discuss taboos can be explained through the liminal phase concept [19]: during this phase the youth are engaged and united in a period of reflection. This phase is also enhanced by practices of social movements, including the film-workshops and critical place-based education which creates moments of reflection on their own realities and enhances students' capacities to articulate themselves.

Interestingly, the young agroecologists who identify themselves as sons and daughters of farmers, young peasants, students, and activists themselves use the word 'resignificar' for agroecological farming practices they and/or their parents appropriated. These young people are conscious of the politics of resignification as described by Lloyd [28] and Butler [29]. Young people acquired the abilities for these resignification practices at critical place-based education initiatives by social movements. By resignifying farming practices toward social-ecological sustainability, the youth contribute to sustainable agro-forest landscapes. This indicates that resignification processes are an essential part of the social system within the social-ecological system approach. Indeed, the films themselves can be understood as examples of framing strategies that others can learn from.

The social-economic situation of these young peasants partly explains the frame transformation of agroecology to the ecology of the system of natural products. The processing of food, wood, popular art, medicinal plants, clothes, biodegradable cleaning and body products among other natural products without the use of chemicals and other external inputs characterizes repeasantization as a transition pathway toward agroecology. Subsequently, young peasants and female farmers foresee possibilities in producing a variety of products to achieve financial autonomy as noted during the interviews. The films underline that this diversification relies on the co-production (sharing of knowledge, skills, affinity and workforce) among populations, generations, and gender in addition to co-production of humans and living nature as described by Van der Ploeg [6] (p. 35).

Critical place-based education and social movement practices in Zona da Mata are directed toward valorizing peasant culture to engage young and traditional—and conventional—farmers in a process of valorizing traditional knowledge on sustainable farming practices such as intercropping, and understanding their place in society. The first focus of this type of education is repeasantization, in the quantitative and qualitative meaning of the word, without making explicit use of the word 'repeasantization'. Agroecology is only introduced after some time when the young people from conventional farms acknowledge the legacy of the peasantry and naturally encounter the term agroecology at various occasions. Statements of the filmmakers indicate that by following Educação do Campo and/or LICENA, critical place-based education, they recognize existing agroecological farming practices at their homes and start new agroecological farming practices, such as an agroforestry system 
or a women's production collective. It is the use of Freire's [24] pedagogy, which emphasizes the diversity among students and the value of local culture, that distinguishes this type of education from other agricultural education.

It is important to highlight the positive affirmation of agroecology that can result from resignifying a broad range of practices by young people. Young people do not refer to the dominant discourse which is about young people leaving the countryside. Their films, for example 'Flowers to live' reveal what attracts them, their values and beliefs, their affect with nature and with local culture, and how both are intertwined. While 'green revolution' techniques were only partially adopted due to the high costs involved [17], values and beliefs around nature were amplified in the films the young people made. More generally, farmers' engagement in agroecology and in transformative learning processes in the past three decades in Zona da Mata have led to a revival of traditional knowledge and a strengthening of farmers' relationships with nature and local culture [17].

\section{Conclusions}

The films and interviews show that the rise of critical place-based education in Brazil has been essential for repeasantization. Repeasantization as both a quantitative movement of especially youth returning or starting to farm and as a qualitative movement that involves co-production between humans and nature to strengthen peasant livelihoods. The pedagogy of Freire, used in critical place-based education in Brazil, engaged youth in a process of valorizing and re-working peasant knowledge and values. The young people build on the frames they already have to resignify such values and, thus, to help redefine agroecology [32]. The making of films, which includes selecting film scenes, characters, titles, and so on, is a meaningful tool in this process.

This study shows how space for young agroecologists to re-signify agroecology can be constituted and extended. Next to critical place-based education, the social-economic situation of these young peasants and the liminal phase ensured the capacities of young agroecologists, their so called "situated ability" [39], to refine their notion of agroecology and engage in framing strategies. These framing strategies includes bridging with social movements and building on peasant values. Strategies to resignify are on the one hand applied to resignify existing sustainable farming practices of women, traditional farmers, indigenous farmers, black farmers at Quilombolas as agroecological practices and, on the other hand to existing unsustainable farming practices at their homes and communities by transforming these to agroecological practices. To do this they build on the legacy of the peasantry.

In conclusion, this study confirms that young people have an important role in the transition toward agroecology [9-12]. By resignifying agroecology as a transition movement for sociobiodiversity, youngsters are opening up spaces for women, black, indigenous, urban, and LGBTs in the agroecological movement. In addition, by following critical place-based education directed toward agroecology, young farmers build on peasant knowledge and contribute to the transformation of farming practices and landscapes by expanding and transforming that knowledge. The transition toward agroecology itself is thus resignified as a movement of repeasantization that reworks local culture so that it is more inclusive of different populations, generations and genders, and that fosters an appreciation of co-production and the interconnectedness of humans and nature.

Supplementary Materials: The following films are available online at http:/ / www.mdpi.com/2071-1050/11/1/ 197/s1, Video S1. Produção de farinha/Making of flower; Video S2. Carneiro Hidráulico/Water pump; Video S3. Plantas Medicinais/Medicinal plants; Video S4. Film at Quilombola Macaúbas Palmito without title.

Author Contributions: Conceptualization: M.G.; methodology: M.G.; formal analysis: M.G. and I.d.S.L.; investigation: M.G. and L.v.d.B.; writing—original draft preparation, M.G.; writing — review and editing: J.B., I.d.S.L., E.T., L.v.d.B., and G.V.; supervision, I.d.S.L., E.T., J.B., and G.V.

Funding: This study was financed in part by the Coordenação de Aperfeiçoamento de Pessoal de Nível Superior-Brazil (CAPES)_Finance Code 001.

Acknowledgments: We like to thank M.I.V. Botelho, previous supervisor of M. Goris and L. van den Berg, for her valuable contributions to the research. Additionally, we like to thank I.M. Cardoso, H. Mancini Teixeira, and L. Carvalho for organizing together an action research with farmers unions in Zona da Mata. Especially we like to 
thank all the youth from Zona da Mata Mineira, Brazil who co-organized, participated in the film workshops and who gave us their informed consent to use their films for research purposes. Finally, we would like to thank the anonymous reviewers of Sustainability for their constructive feedback and Kelli Rose Pearson, Stella Maria Pennell, and Tara Goris for their proof-reading of the manuscript.

Conflicts of Interest: The authors declare no conflict of interest.

\section{References}

1. Gliessman, S. Defining Agroecology. Agroecol. Sustain. Food Syst. 2018, 42, 599-600. [CrossRef]

2. Rivera-Ferre, M.G. The resignification process of Agroecology: Competing narratives from governments, civil society and intergovernmental organizations. Agroecol. Sustain. Food Syst. 2018, 42, 666-685. [CrossRef]

3. Wezel, A.; Goris, M.; Bruil, J.; Félix, G.F.; Peeters, A.; Bàrberi, P.; Bellon, S.; Migliorini, P. Challenges and Action Points to Amplify Agroecology in Europe. Sustainability 2018, 10, 1598. [CrossRef]

4. Pimbert, M. Agroecology as an Alternative Vision to Conventional Development and Climate-smart Agriculture. Development 2015, 58, 286-298. [CrossRef]

5. van den Berg, L.; Hebinck, P.; Roep, D. 'We go back to the land': Processes of re-peasantisation in Araponga, Brazil. J. Peasant Stud. 2018, 45, 653-675. [CrossRef]

6. van der Ploeg, J.D. The New Peasantries: Struggles for Autonomy and Sustainability in an Era of Empire and Globalization; Earthscan: London, UK, 2012.

7. Altieri, M.A.; Nicholls, C.I. Agroecology: A brief account of its origins and currents of thought in Latin America. Agroecol. Sustain. Food Syst. 2017, 41, 231-237. [CrossRef]

8. Garcia Júnior, A.R. O Sul: Caminho do Roçado-Estratégia de Reprodução Camponesa e Transformação Social; Marco Zero/EdUnB: São Paulo/Brasília, Brazil, 1989.

9. Cacho, M.M.; Giraldo, O.F.; Aldasoro, M.; Morales, H.; Ferguson, B.G.; Rosset, P.; Khadse, A.; Campos, C. Bringing agroecology to scale: Key drivers and emblematic cases. Agroecol. Sustain. Food Syst. 2018, 42, 637-665. [CrossRef]

10. Moura, N.F.; Ferrari, E.A. Juventudes e Agroecologia: A Construção da Permanência no Campo na Zona da Mata Mineira; ANA: Rio de Janeiro, Brazil, 2016.

11. Londres, F.; Petersen, P.A.; Martins, G. Olhares Agroecológicos, Análise Econômico-Ecológica de Agroecossistemas em sete Territórios Brasileiros, Agroecologia; AS-PTA: Rio de Janeiro, Brazil, 2017.

12. McCune, N.; Rosset, P.M.; Salazar, T.C.; Saldívar Moreno, A.; Morales, H. Mediated territoriality: Rural workers and the efforts to scale out agroecology in Nicaragua. J. Peasant Stud. 2017, 44, 354-376. [CrossRef]

13. Farshad, A. Araghi Global Depeasantization, 1945-1990. Sociol. Q. 1995, 36, 337-368.

14. Rosset, P.M.; Martinez-Torres, M.E. La Via Campesina and Agroecology; La Via Campesina: Mons, Belgium, 2013.

15. Jurna, I. Pathways of Rural Youth in Brazil, Narratives about Staying and Leaving the Countryside; Wageningen University: Wageningen, The Netherlands, 2017.

16. Brumer, A. Gender Relations in Family-Farm Agriculture and Rural-Urban Migration in Brazil. Lat. Am. Perspect. 2008, 35, 11-28. [CrossRef]

17. Botelho, M.I.V.; Cardoso, I.M.; Otsuki, K. "I made a pact with God, with nature, and with myself": Exploring deep agroecology. Agroecol. Sustain. Food Syst. 2016, 40, 116-131. [CrossRef]

18. Ghimire, K.B. Social Movements and Marginalized Rural Youth in Brazil, Egypt and Nepal. J. Peasant Stud. 2002, 30, 30-72. [CrossRef]

19. Turner, V. Betwixt and between: The liminal period in "rites de passage.". In Symposium on New Approaches to the Study of Religion; American Ethnological Society: Malden, MA, USA, 1964.

20. Ryan, M.E. Critical pedagogy and youth: Negotiating complex discourse Worlds. Pedagogy Cult. Soc. 2007, 15, 245-262. [CrossRef]

21. de Castro, E.G. PNRA e Juventude Rural: 30 anos Depois-balanço e Apontamentos em um Contexto de Ruptura Institucional. Retratos Assentamentos 2016, 19, 98-124.

22. Rossato, A. A Recepção de Rádio e Televisão por Jovens do Movimento dos Atingidos por Barragens: As Representações da Classe Popular; Federal University of Santa Maria: Santa Maria, CA, USA, 2008.

23. Santos, R.B. Histora da educação do campo no brasil: O protagonismo. Rev. Teias 2017, 18, $210-224$.

24. Freire, P. Pedagogia da Esperança: Um Reencontro com a Pedagogia do Oprimido, 17th ed.; Paz e terra: São Paulo, Brazil, 2011. 
25. Howarth, D. Complexities of identity/difference: Black Consciousness ideology in South Africa. J. Polit. Ideol. 1997, 2, 51-78. [CrossRef]

26. Cardoso, I.M.; Mendes, F. People managing landscapes: Agroecology and social processes. In Agroecology for Food Security and Nutrition, Proceedings of the FAO International Symposium, 18-19 September 2014, Rome, Italy; FAO: Rome, Italy, 2015.

27. Lloyd, M. Radical Democratic Activism and the Politics of Resignification. Constellations 2007, 14, 129-146. [CrossRef]

28. Butler, J. Critically Queer. GLQ 2018, 1, 17-32. [CrossRef]

29. van der Ploeg, J.D. The Importance of Peasant Agriculture: A Neglected Truth; Wageningen University \& Research: Wageningen, The Netherlands, 2016.

30. Benford, R.D.; Snow, D.A. Framing Processes and Social Movements: An Overview and Assessment. Annu. Rev. Sociol. 2000, 26, 611-639. [CrossRef]

31. van Dijk, T.A. Movimentos sociais, frames e cognição: Uma revisão crítica. Rev. Investig. 2017, 30, $173-219$.

32. Holt-Giménez, E. From Food Crisis to Food Sovereignty: The Challenge of Social Movements. Mon. Rev. 2009, 61, 142-156. [CrossRef]

33. Dapia, S.G. Logics of Antagonism, of Difference, and of the Limit: Questions of Cultural Identity in Latin America Cultural Studies. Dialogos Latinoamer. 2000, 1, 9-32.

34. Alves, M.A. A "Conquista da terra": (re)produção social e (re)construção histórica entre agricultores familiares do município de Araponga-MG. MANA 2006, 12, 269-283. [CrossRef]

35. Griggs, S.; Howarth, D. Populism, Localism and Environmental Politics: The Logic and Rhetoric of the Stop Stansted Expansion campaign. Plan. Theory 2008, 7, 123-144. [CrossRef]

36. Shanley, P.; Da Silva, F.C.; MacDonald, T. Brazil's Social Movement, Women and Forests: A Case Study from the National Council of Rubber Tappers. Int. For. Rev. 2011, 13, 233-244. [CrossRef]

37. Declaration of the International Forum for Agroecology, Nyéléni, Mali: 27 February 2015. Development 2015, 58, 163-168. [CrossRef]

38. Howarth, D.; Glynos, J.; Griggs, S. Discourse, explanation and critique. Crit. Policy Stud. 2016, 10, 99-104. [CrossRef]

39. Leroy, P.; Horlings, I.; Arts, B. Het ontbrekende hoofdstuk; Theorie en samenleving als inspiratiebron voor een goede vraagstelling. In Voer voor Methodologen, Een Liber Amicorum voor P. Verschuren; Bleijenbergh, I., Korzilius, H., Vennix, J., Eds.; RUN: Nijmegen, The Netherlands, 2009; pp. 141-156.

40. Reason, P.; Bradbury, H. The SAGE Handbook of Action Research: Participatory Inquiry and Practise, 2nd ed.; SAGE: Los Angelos, CA, USA; London, UK, 2008.

41. Heath, C.; Hindmarsh, J.; Paul, L. Video in Qualitative Research, Analysing Social Interaction in Everyday Life; SAGE: London, UK, 2010.

42. Goris, M.; Witteveen, L.; Lie, R. Participatory film-making for social change: Dilemmas in balancing participatory and artistic qualities. J. Arts Commun. 2015, 7, 63-85. [CrossRef]

43. Orbach, A.; Rain, J.; Contreras, R. Community filmmaking as research: (re)considering knowledge production through the camera's lens. Dev. Pract. 2015, 25, 478-489. [CrossRef]

44. Peters, M.A.; Wals, A.E.J. Transgressive learning in times of global systemic dysfunction: Interview with Arjen Wals. Open Rev. Educ. Res. 2016, 3, 179-189. [CrossRef]

45. Laclau, E.; Mouffe, C. Hegemony and Socialist Strategy: Toward a Radical Democratic Politics, 2nd ed.; Verso: London, UK; New York, NY, USA, 2001.

46. Calvet-Mir, L.; Benyei, P.; Aceituno-Mata, L.; Pardo-de-Santayana, M.; López-García, D.; Carrascosa-Garía, M.; Perdome-Molina, A.; Reyes-Garíca, V. The Contribution of Traditional Knowledge as a Digital Commons to Agroecological Transitions: The Case of the CONECT-e Platform. Sustainability 2018, 10, 3214. [CrossRef]

47. Gohn, M.G. Movimentos sociais na contemporaneidade. Rev. Bras. Educ. 2011, 16, 333-362. [CrossRef]

(C) 2019 by the authors. Licensee MDPI, Basel, Switzerland. This article is an open access article distributed under the terms and conditions of the Creative Commons Attribution (CC BY) license (http://creativecommons.org/licenses/by/4.0/). 